Civic Review, Vol. 16, Special Issue, 2020, 9-31, DOI: 10.24307/psz.2020.1202

\title{
György Matolcsy \\ Quo vadis Hungaria? - Facing a New World
}

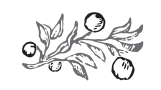

\section{Summary}

Over the past decade, the Hungarian economy has achieved unique successes building on the fiscal and monetary policy turnaround implemented in the early 2010's. The targeted measures of the government and the central bank have helped to put the Hungarian economy on a sustainable convergence path, and at the same time, they have strengthened the immune system of the economy. As a result, the Hungarian economy has been properly prepared to face the crisis caused by the coronavirus pandemic recently. However, in addition to addressing the short-term consequences, a longer-term perspective must be continously kept in mind as well. Only countries that are rapidly adapting to the norms of the new - post-Covid-19 pandemic - world, will be able to win the next decade. The norms of the 21st century are just taking shape, so every country has a chance to become a frontrunner. To continue the economic catch-up process, Hungary's growth model needs to be further developed and adjusted to these new megatrends, and monetary policy must play an active role in this change.

Journal of Economic Literature (JEL) codes: E52, E61, G01, H12, O23

Keywords: monetary policy, competitiveness, crisis management, Covid-19 pandemic, money creation, economic development, digital central bank money, monetisation of debts, hybrid financial system

Dr GyöRgy Matolcsy is Governor of the Magyar Nemzeti Bank (matolcsygy@ mnb.hu). 
György Matolcsy: Quo vadis Hungaria? - Facing a New World

\section{FACING A NEW WORLD}

Hungary faced the Covid-19 pandemic and its economic effects with strong fundamentals, significant reserves and adequate room for manoeuvre in economic policy. The Hungarian economy and economic policy have come a long way in the last ten years to achieve this favourable position. While the 2008 global financial crisis hit Hungary "in an extremely weakened state" (Matolcsy, 2019), the economic immune system has since strengthened and is ready to overcome threatening trials. However, it would be a fatal mistake to look presumptuously at the next period. Uncertainty remained, with international economic and financial developments following a rapidly changing trajectory.

Economic policy cannot rely on well-established recipes. We have to retain successful, well-proven components, but break away from previously failed approaches and manoeuvre based on lessons learnt. By recognising the internationally emerging megatrends and turning them to our advantage, and taking into account domestic peculiarities, we can develop a winning economic strategy promoting a successful economic convergence for Hungary in the coming years and decades as well.

\section{WHAT HAS HAPPENED TO CENTRAL BANKS OVER THE LAST TEN YEARS?}

Over the past decade, the external monetary policy environment has changed significantly

In response to the 2008-2009 global economic crisis and to the crisis of confidence, major central banks took significant monetary easing measures. The moderation of interest rate conditions soon ran into the zero lower bound in several countries, prompting monetary policy makers to use unconventional instruments changing the size and/or composition of central bank balance sheets. The most common examples of this, followed by large central banks over the past decade, have been asset purchase programmes, under which these institutions have purchased government securities, corporate bonds and, at times, even equities. As a result of asset purchase programmes, central banks' balance sheet totals have expanded remarkably, and responses to the Covid-19 pandemic have further inflated already increased central bank balance sheets.

Instead of the previous one goal - one instrument approach, central banks are now shaping their monetary policy along the multi-goals - multi-instruments principle, which has also made the instruments more complex. While maintaining the priority of price stability, central banks are paying greater attention to sustainable growth, and the aspect of financial stability has become more important as well.

Central bank measures have become more targeted. The global crisis of 2008-2009 and then the euro area crisis of 2011-2012 resulted in a completely new central bank operation globally. Basically, central banks are no longer trying to influence the economy by shaping the policy rates but, by using a range of new instruments, to influence the entire yield curve. For the asset purchase programmes launched by large central 
Civic Review · Vol. 16, Special Issue, 2020

banks over the past decade, it has been observed that the newer and newer general asset purchase programmes have had less and less impact on financial markets, and their impact on the real economy can also be considered more modest. This has drawn attention to the importance of targeted, unconventional tools.

In order to address the challenges of the decade ahead the coordination of economic policy branches, has become important again. In a complex economic policy, the coordinated and targeted operation of monetary policy, fiscal policy, debt management, competitiveness policy and macroprudential policy can ensure sustainable economic growth.

Unprecedented turnaround at Hungary's central bank

The innovative measures of the Magyar Nemzeti Bank have contributed significantly to the economic convergence in recent years and to the strengthening of the fundamentals of the Hungarian economy. In order to ease monetary conditions, the MNB launched its easing cycle in 2012. As a result, the central bank base rate fell from 7 per cent to a historic low of 0.9 per cent by 2016. Keeping the low base rate on hold has been in line with the achievement of the inflation target in a sustainable manner. At the same time, in 2016 the central bank introduced a new monetary policy framework, which allowed it to implement targeted, unconventional monetary easing in addition to keeping the base rate unchanged and taking into account inflation developments. In a forward-looking way, the new framework ensured that, in addition to the base rate, other targeted instruments would also be available to the central bank in order to achieve its monetary policy objectives (Magyar Nemzeti Bank, 2017a).

The broadening of the central bank's instruments was planned in a targeted approach. Experience from the previous crisis has shown that reaching the lower limit of the base rate and using short-term assets do not effectively shape long-term yields, so influencing monetary conditions in a targeted way requires attention to shaping the entire yield curve.

In recent years, the MNB has made considerable efforts to clean up the retail credit market and make the structure of the loan portfolio healthier, so in the current crisis situation households face a significantly lower risk than during the 2008-2009 crisis. The macrofinancial risks caused by household foreign currency borrowing have virtually disappeared with the forint conversion, markedly reducing Hungary's external vulnerability. The fixing of lending rates instead of short-term, variable interest rates, the encouraging of the extension of interest periods and the introducing of consumer-friendly financial products have helped to make the retail credit market healthier and reduce risks overall (Matolcsy, 2019).

Adequate funding of companies, provided by the central bank through targeted, innovative programmes, plays a key role in sustainable convergence. After the crisis of 2008-2009, Hungary was hit by credit crunch: the shrinking corporate loan portfolio particularly affected micro-, small and medium-sized companies with limited access to other sources of finance. Therefore, in 2013, the central bank launched the Funding for Growth Scheme (FGS), which aimed to alleviate persistent market disturbance in SME lending, 


\section{György Matolcsy: Quo vadis Hungaria? - Facing a New World}

increase banks' willingness to lend, stimulate the economy and strengthen financial stability. Beyond improving conditions for access to credit for SMEs, the first three phases of the Funding for Growth Scheme have had a significant impact by restoring a previously dysfunctional credit market (Figure 1), which has made a further lasting contribution to economic expansion (Matolcsy, 2020a). All in all, in the first three phases of the FGS, nearly 40,000 domestic enterprises received funding in the amount of about HUF 2,800 billion (Magyar Nemzeti Bank, 2019a). In 2019, another phase of the FGS was launched under the name of FGS $f i x$, aimed at creating a healthier credit structure and supporting the shift towards longer maturities.

Figure 1: Growth rate of total corporate and SME sector loan portfolio

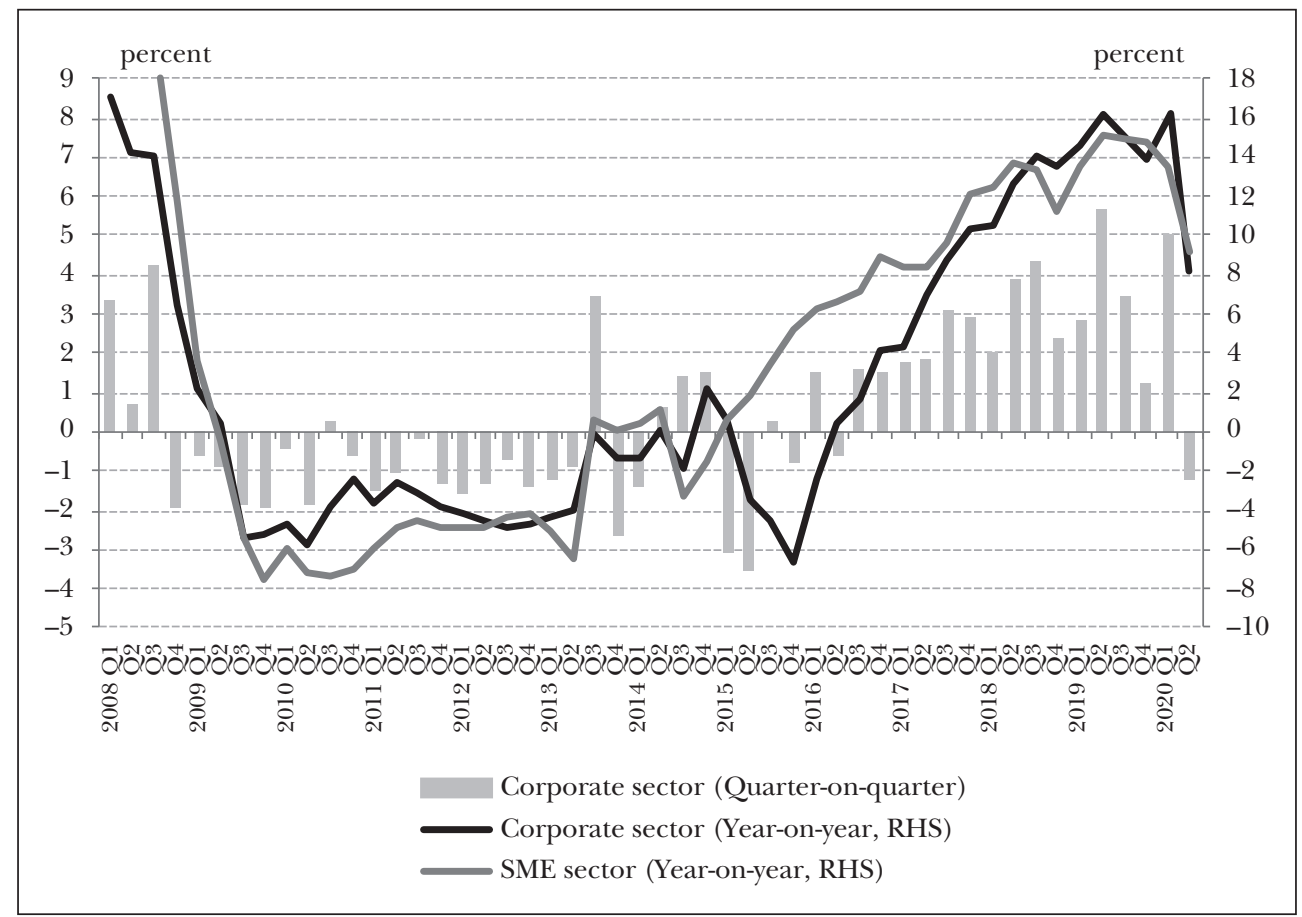

Note: Transaction-based, with the SME sector estimated on the basis of banking system data before the fourth quarter of 2015.

Source: $M N B$

Diversification of corporate fund-raising is beneficial to reduce risks, moderate fund-raising costs and strengthen competition as well. Therefore, in the summer of 2019, the central bank launched the Bond Funding for Growth Scheme, which allows domestic - primarily medium and large - companies to rely on other funding forms in addition to bank loans. This contributes to improving the efficiency of monetary policy transmission, this new market also supports more effective enforcement of interest rate decisions by the central bank (Magyar Nemzeti Bank, 2019b). 
With its instruments, the central bank has shaped monetary conditions, firstly, to support investment, strengthen employment and thus economic growth, and secondly, to ensure a healthy, sustainable balance between consumption and saving. For investors, the Funding for Growth Scheme and the Bond Funding for Growth Scheme provide cheap, negative real interest rate funds that contribute to a healthy structured credit expansion.

The innovation of the new Hungarian economic model was that domestic monetary policy was able to substantially loosen monetary conditions, stimulate lending by targeted measures and reduce the vulnerability of the economy while the central bank balance was shrinking. Contrary to global trends, since 2013 the MNB has focused on the effective restructuring of the balance sheet rather than a general increase (Figure 2), so there is still considerable room for manoeuvre to overcome the challenges in the Covid-19 era (Csortos and Nagy-Kékesi, 2020).

Figure 2: International comparison of the liabilities side of central bank balance sheets

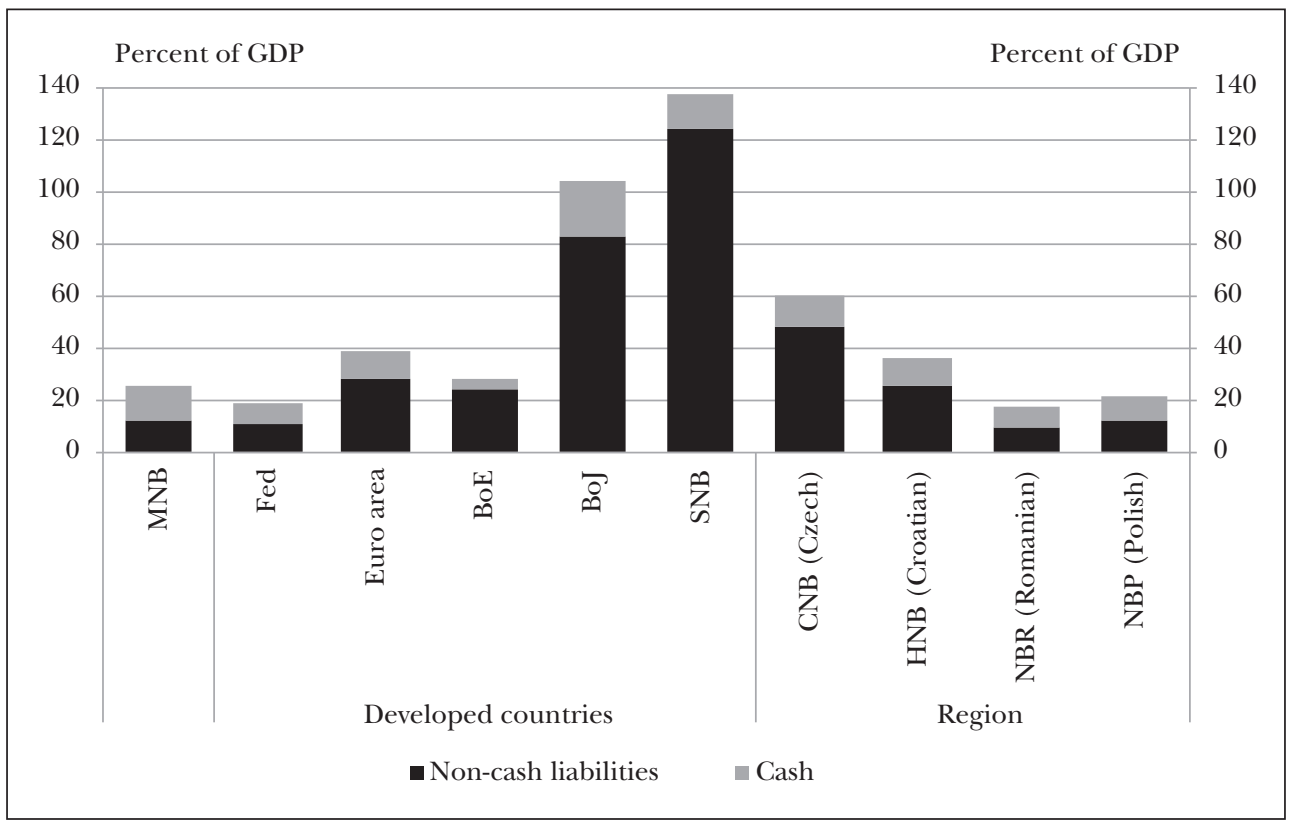

Note: The liability side of the central bank balance sheets are calculated from the end of 2019.

Source: Central bank websites, $M N B$

Monetary policy turnarounds in the last seven years, which helped to put the Hungarian economy on a sustainable convergence path, also strengthened the immune system of the economy. Due to this, Hungary has been able to face the crisis caused by the Covid-19 pandemic with a sound economy. The next seven years are expected to be more difficult, more uncertain, with stronger risks, greater challenges but at the same time, the opportunities will be big: whoever wins can win big compared to their competitors (Matolcsy, 2020b). 
György Matolcsy: Quo vadis Hungaria? - Facing a New World

\author{
MEGATRENDS DEFINING THE 21 ST CENTURY - \\ OPPORTUNITIES FOR OVERTAKING ON THE BEND
}

The 21st century has brought with it a powerful movement of the tectonic plates of the world economy and geopolitics, so if we step on a high plate with good strategy and a sense of pace, we can become the winner of the 21st century. The balance between competition and cooperation creates a new world order in which new norms will apply. The emergence of this world order based on new norms is accelerated by the social, economic, mindset-related, i.e. system-level effects of the global coronavirus crisis. And we need to create balance and growth in the new world, too. Seven major emerging megatrends can be identified in the 21 st century from the current situation assessment (Figure 3).

Figure 3: The seven major megatrends characterizing the 21st century

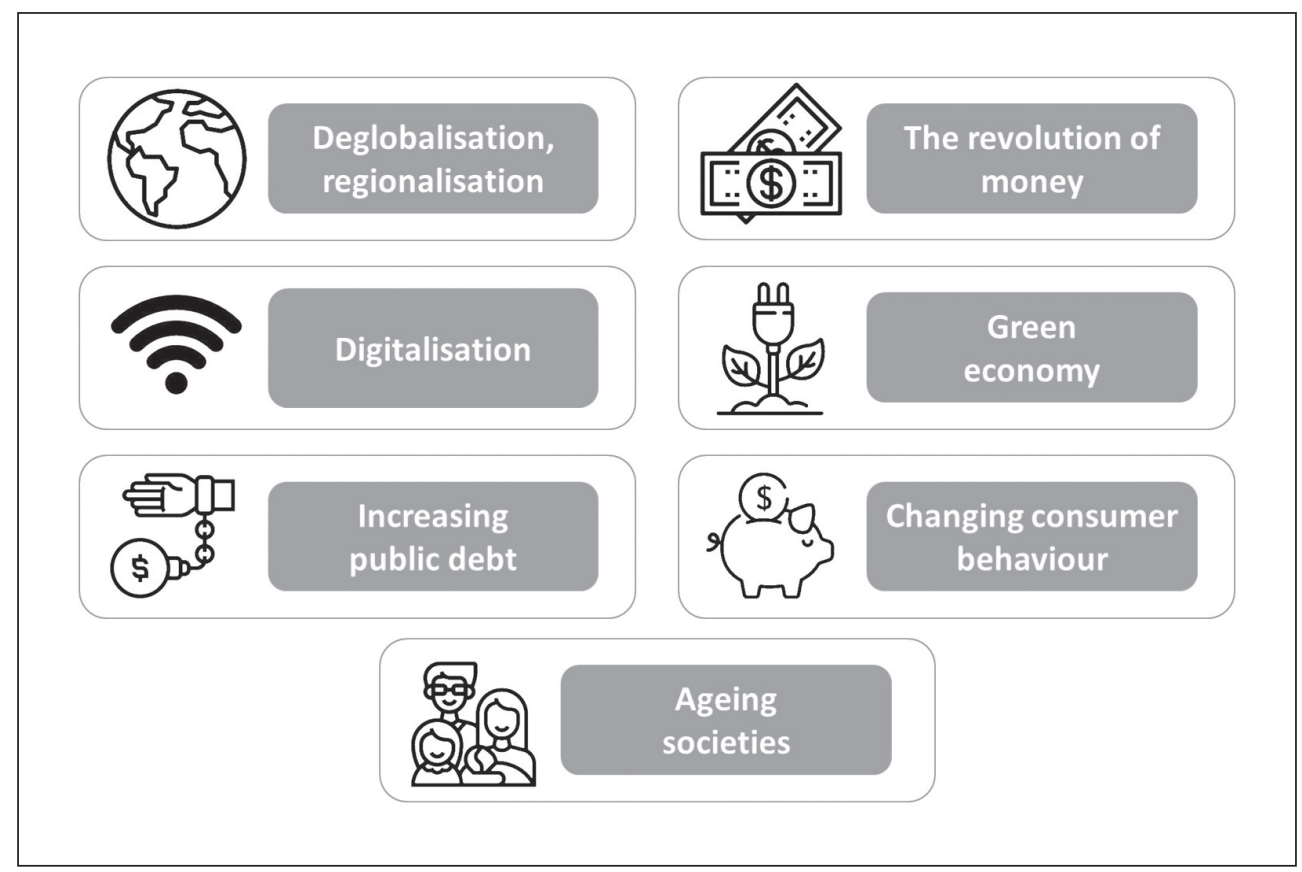

Source: $M N B$

\title{
1. Deglobalisation, regionalisation
}

Super-globalisation, the age of economic value creation with the disappearance of national frameworks, is being replaced by a period of deglobalisation, local and regional production and provision of services. To reduce production costs and serve consumer needs at a massive scale, large companies have created long, cross-border global value chains in order to create value with the greatest possible profit. In a global production organisa- 
Civic Review · Vol. 16, Special Issue, 2020

tion, production and service activities are based on international outsourcing and low stockholding, which, however, involves significant risk. Therefore, during economic recovery, multinational companies can shorten global value chains, make them more regional, multicentre their supplier base and increase their security stocks in response to current problems. Hungary can improve its position in the world economy by attracting corporate activities relocated from distant countries to Europe and further strengthening its participation in regional cooperation.

We have seen that sovereign countries have been able to respond more effectively to the Covid-19 pandemic than the international community and multilateral organisations. Regional cooperation is also strengthening. We are already seeing some of the results of this in our narrower region in the form of the strengthening cooperation of the Visegrád Four, the successes of the Three Seas Initiative or the emerging Carpathian Basin Economic Cooperation. And in our wider Eurasian region, the Belt and Road Initiative can support the joint construction activity of countries in the region. All this is happening at a time when international trade conflicts and internal disputes in the euro area are intensifying along the fault lines between the northern and southern member states, but the Central and Eastern European region remains an area of stability and prosperity.

\section{Digitalisation}

Digitalisation is transforming our everyday life and our work as well. The future will be not only local and regional but also digital. Due to the coronavirus, the information economy has started to develop rapidly, which can not only help spread the achievements - cyberphysical systems, the internet of things, smart factories, big databases - of today's fourth industrial revolution throughout the economy and society but also contribute to the unfolding of the fifth industrial revolution which is based on artificial intelligence and which fundamentally changes the social structure. Digital economic activities - even in the narrow sense - accounted for 7 per cent of Hungary's GDP in 2018, which is at the forefront in the EU, and may continue to increase in the coming years. This process, while leading to the loss of low-complexity jobs, is creating many new, more complex jobs, similar to previous industrial and technological revolutions. A good example of this is the decline of labour in agriculture, as we no longer harvest and thresh by hand, or the fact that there is no need for call centre coordinators, but new occupations such as programmer or data expert are emerging. It is not the disappearing jobs but the workforce that need to be protected, so it is necessary to ensure their flexibility in the new world through skills- and practice-oriented vocational and further training, while increasing the number of tertiary education graduates is also a key to success. The consequence of mass digitalisation is that in the 21 st century, instead of raw material, data is becoming the new central resource, the protection of which requires nationally-developed cyber defence systems and the expansion of IT knowledge capital. 


\section{György Matolcsy: Quo vadis Hungaria? - Facing a New World}

\section{Increasing debts}

Mass digitalisation will require large-scale investment, which in turn will require the raising of a significant amount of new capital. However, the average gross public debt of developed countries already exceeds 100 per cent of their GDP (International Monetary Fund, 2020; Figure 4). Contrary to this international trend, Hungary's gross public debt ratio has declined every year since 2012 and has fallen to 65.4 per cent of GDP by 2019, due to the successful post-2010 crisis management and growth-enhancing reforms. In addition to the level of debt, its structure is also important. From both an economic policy and a national strategic point of view, it is important for public debt to be in domestic hands and domestic currency, as this reduces a country's external financial vulnerability. The effectiveness of the Hungarian debt strategy is shown by the fact that between 2011 and 2019, the share of foreign holdings of Hungarian public debt decreased from 65 to 34 per cent, and the foreign exchange ratio of central debt from about 49 to 17 per cent. The MNB's Self-financing Programme also made a significant contribution to this success. The achievement of a sustainable debt structure was also supported by the market launch of the Hungarian Government Securities Plus in 2019, which led to a further increase in the share of government securities held by households.

Figure 4: Gross public debt as a share of GDP in developed countries and in Hungary

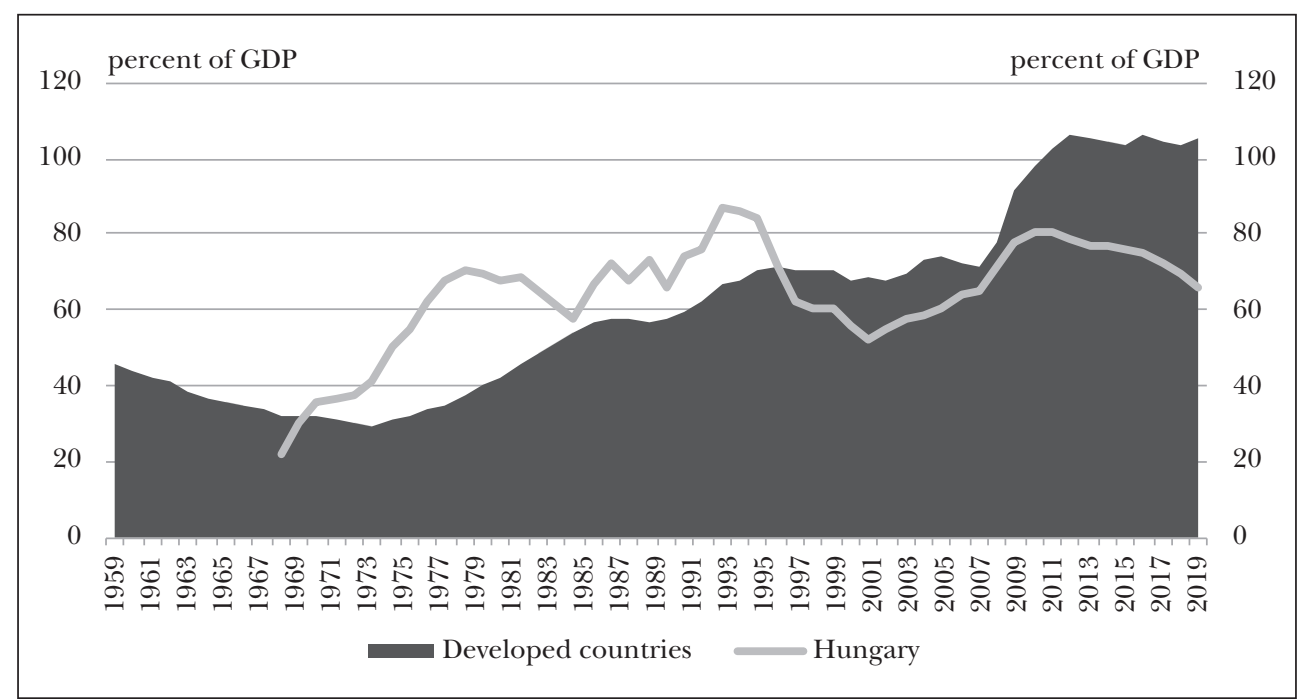

Note: The average for developed countries is based on the government debt data of Australia, Austria, Belgium, Canada, Denmark, Finland, France, Germany, Greece, Hong Kong, Ireland, Italy, Japan, Korea, New Zealand, Norway, Portugal, Singapore, Spain, Sweden, Switzerland, Taiwan, the Netherlands, the United Kingdom and the United States.

Source: International Monetary Fund, 2018; 2020; Eurostat, MNB 
Civic Review · Vol. 16, Special Issue, 2020

A competitive tax system and a sufficiently diversified financing system can result in sustained high investment activity and sustainable convergence. In addition to sustainable debt management, the dynamic expansion of the economy also requires a growth-friendly tax system, for the development of which Hungary has taken significant steps over the past ten years. The philosophy of the employment and investment incentive tax system is to shift the focus of tax centralisation from taxes on labour and capital to consumption taxes, i.e. it taxes income not when it is generated but when it is spent (Matolcsy and Palotai, 2018). The next stage in the development of this competitive tax system could be the national taxation of cross-border digital services and the more active use of green taxes for polluting activities.

In addition to the development of a modern tax system, a new financial system is needed in Hungary, in which, besides the dominant bank financing, equity-, mortgage bond-and bondbased financial funding will be strengthened. To this end, the central bank took the strategically important stock exchange into domestic hands and launched the Bond Funding for Growth Scheme, which stimulates the issuance of corporate bonds. The listing of companies on the stock exchange and their participation in the bond programme can help them move up in size, which can also contribute to the improvement in their productivity and the emergence of domestically owned corporate champions.

\section{The revolution of money}

The 21st century is bringing the acceleration of financial innovations so far, which will further strengthen central banks. Financial digitalisation is reflected in the increase in the share of electronic payments, the introduction of instant transfer systems and the realisation of digital central bank money (see below). Due to the financial revolution, access to money will generally be fast, cheap and secure. It will be typical for countries opting for financial competitiveness that instead of aid or basic income, their citizens have a basic credit line calculated on the basis of the expected career income. In such countries, it is not fish (aid, basic income) but net (basic credit line) that is provided to everyone (Matolcsy, 2020c). Hungary is at the forefront among the EU member states in terms of the practical implementation of financial innovations.

\section{Green economy}

Green taxes and greening of financial products can help preserve the natural environment. "We haven't inherited the Earth from our ancestors, we're borrowing it from our children”, said David Brower, a famous environmental activist. At present, however, the population of the Earth uses more than one and a half times as many resources as our planet can still provide through its renewable capacity. Hungary has no reason to be ashamed in this area either. Our country has the fourth lowest per capita carbon dioxide emissions in the EU (Figure 5). For a greener economy, and in order for those concerned to pay for the costs of pollution, legal and financial regulatory instruments need to be introduced. One effective financial regulatory tool is to apply green taxes 


\section{György Matolcsy: Quo vadis Hungaria? - Facing a New World}

to environmentally harmful activities. Through the development of green investment portfolios, the financial system can support natural resources and environmental services to be provided also for future generations. The Central Bank of Hungary, too, prioritises the issue of green future, as our institution has a comprehensive Green Programme based on three pillars and was among the first ones to create a separate green bond portfolio in its foreign exchange reserves.

Figure 5: Carbon dioxide emissions per capita in member states of the European Union (2018)

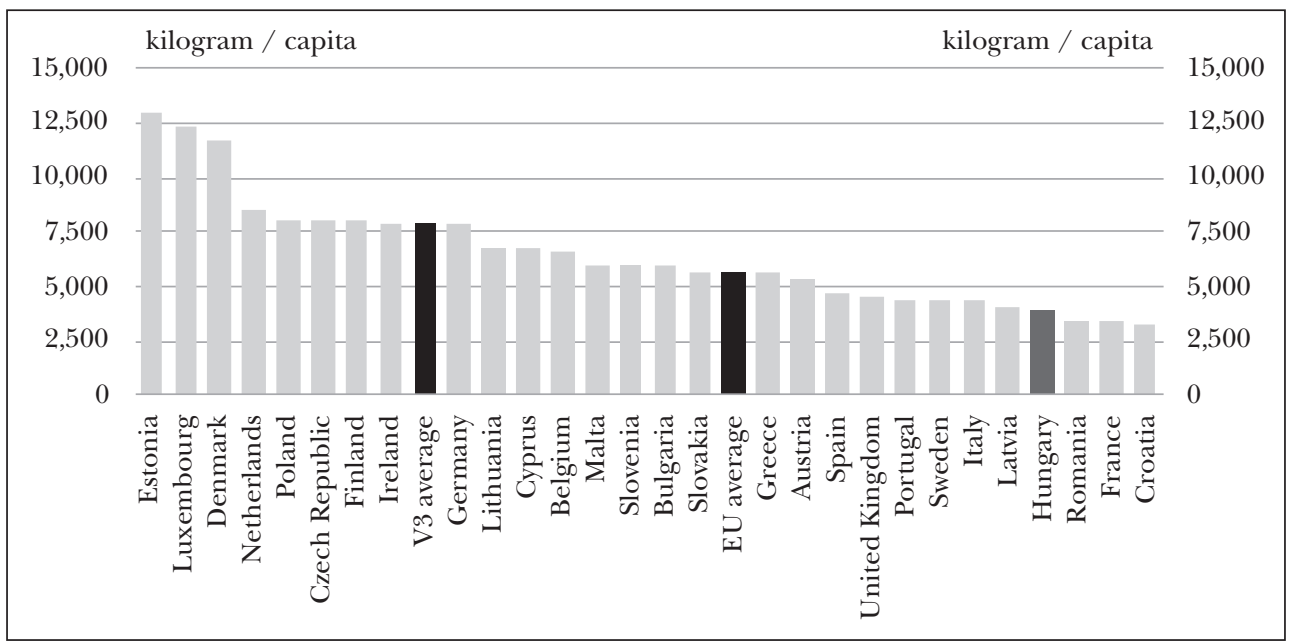

Note: EU and V3 values are averages weighted by the population of countries.

Source: Eurostat

\section{Changing consumer habits}

The competitiveness of the national economy will be determined by whether individual countries are able to react in time to changing consumption habits, to the accelerating expansion of services and to the transformation of household saving patterns. The rearrangement of the weight of the main production sectors of the economy in GDP is a well-documented phenomenon in the development path of economies, where the weight of the service sector shows a continuous increase. In the OECD countries, the average weight of services in gross national product is 70 per cent, whereas in Hungary this proportion is 55 per cent. It is therefore expected that in the coming decades, with the increasing digital transformation, the globalisation of services and the changes in consumer habits, their share in the creation of economic value will increase (Magyar Nemzeti Bank, $2017 \mathrm{~b})$. At the same time, within the service sector, a transformation is expected: the weight of traditional activities (e.g. transport, event organisation) may decrease and the share of modern electronic services (e.g. e-commerce, digital entertainment) may increase. The gaining ground of services also means an opportunity for Hungarian SMEs to find new entry points into international trade through exports of services. 
Civic Review · Vol. 16, Special Issue, 2020

However, the expansion of services is a challenge for the economics profession, too. Measuring value added and inflation of services - as opposed to the established quantification of industrial value creation - is still a serious professional task, and as the complexity of the sector increases, this task is expected to become even more difficult. Reforming the measurement of inflation and using "big data" technologies and artificial intelligence in statistical work can be of great help in solving this challenge (Matolcsy et al., 2019). The transformation of consumer habits will also be reflected in savings. While in the case of the so-called boomer (born between 1945-65) and X (born between 1965-80) generations, individuals started saving in their early 30s, the millennium (born between 1980-95) generation starts to set aside a portion of their income as early as at the age of 24 . Smart states react quickly to this phenomenon.

\section{Ageing societies}

Population decline and ageing in Europe can be reversed by well-targeted family-friendly policy. According to UN projections, the number of people on Earth could be close to even 10 billion by 2050 , but different trends are expected from continent to continent (United Nations, 2019). While the proportion of people living in Africa will increase from 16 per cent to 26 per cent, that of people living in Europe will fall from 10 per cent to 7 per cent between 2015 and 2050. One of the biggest challenges for the economies of the developed world could be the ageing of society over the next few decades, caused by an increase in life expectancy and a decline in fertility rate. The total fertility rate of 2.1 needed to maintain the population of the countries was not reached by any EU member state in 2018 . The old-age dependency ratio - i.e. the ratio of the number of people over 65 to the number of those of working age - could double between 2015 and 2050, both globally and in Europe. As a result, by 2050, instead of the current 4 or so, only 2 working-age adults will have to provide care for 1 elderly person on our continent. Unfavourable demographic conditions and changes can have strong economic consequences in both developed and underdeveloped regions: they can transform the labour market and pose serious challenges to pension and health care systems (Kreiszné Hudák and Rippel, 2019). Therefore, it is to be welcomed that from 2010, the Hungarian government started to pursue a family policy, the first fruits of which are already visible in our country. The fertility rate increased from 1.2 to 1.5 between 2010 and 2019, and the number of marriages doubled. Achieving a complete demographic turnaround requires the continuation of this family policy and, depending on economic opportunities, ever-expanding family-friendly measures are needed.

The new norms of the 21st century are still young and can be shaped, so every country - including Hungary - has a similar chance to become a frontrunner in the megatrends presented. The sooner a country acts, the sooner it gains a competitive advantage. Let us not be afraid to take advantage of the new megatrends - i.e. key factors for future competitiveness - intensifying due to the coronavirus, and let us dare to overtake even on the bend while complying with the rules! To quote Lao Tzu: "A journey of a thousand 
György Matolcsy: Quo vadis Hungaria? - Facing a New World

miles begins with a single step." It is worth taking this single step in all areas as soon as possible, so that Hungary can be among the most competitive countries of the 21st century.

\section{NEW TRENDS EMERGING WITH THE CORONACRISIS - \\ THE WORLD IS CHANGING, LET US TAKE THE LEAD!}

Today, no one can yet tell us how long the disease that is causing the current pandemic will remain with us, but it cannot be ruled out that it may affect our lives in the long run. However, it is important to be open to these changes and to make flexible use of the opportunities they create to implement our old plans or even our new ideas. Let us take the lead in the processes so that when the world gets straightened out again, we should be the ones whose backs the field is looking at. What are the areas where we need to prepare for considerable changes?

My house, my castle - our home is transforming

During the period of confinement, we had to realise that our home needed to serve a lot more functions than before. Home is no longer just a place to live but a place to relax, work, cook, play sports, train ourselves and help our children learn, garden in the garden or on the terrace. Achieving this is not easy even in a family house, while in the case of smaller apartments all the creativity of the Hungarian people was needed to harmoniously coordinate the various functions. We have won this battle, but we must be prepared for the further challenges.

In this preparation, it is extremely important that the economic management pursues an appropriate, long-term sustainable housing policy. Housing policy is one of the largest reserves in Hungary, but its exploitation is only possible along a strategy based on a clear vision (Matolcsy, 2020d). In the early 2000s, we were able to build 30-40 thousand homes a year. Why not achieve this again? To support this, the Housing and Real Estate Market Advisory Board (HREMAB) was established in 2019 on the initiative of the MNB, with the aim of providing a professional forum for relevant participants of the real estate market. It is a big step forward that for new homes built in rusted zones, renting and selling will be taxed at a rate of 5 per cent instead of 27 per cent in the future. Additionally, the value-added tax for new homes will be reduced for 5 percent for the next two years, and families with children are eligible for further allowances. All of these may help to increase housing activity in the coming years, but we also have to develop the construction capacity in order to maintain higher activity over the long term without a hike in housing prices.

Flexibility and competition - our workplace is transforming

The combined implementation of successful pandemic control and maintenance of economic momentum has become feasible with the sharp growth of teleworking. The MNB's own surveys 
showed that Hungarian small and medium-sized enterprises were not really prepared in advance to home office work, but they nevertheless successfully overcame the obstacles. A significant part of the Hungarian economy was able to switch their processes to remote work (Figure 6), making it possible to minimise the economic loss caused by the restrictions. The expansion of these yet unfamiliar forms of employment is essential for the continuation of the Hungarian economy's convergence in recent years.

Figure 6: Evolution of the share of teleworkers or home office workers in Hungary

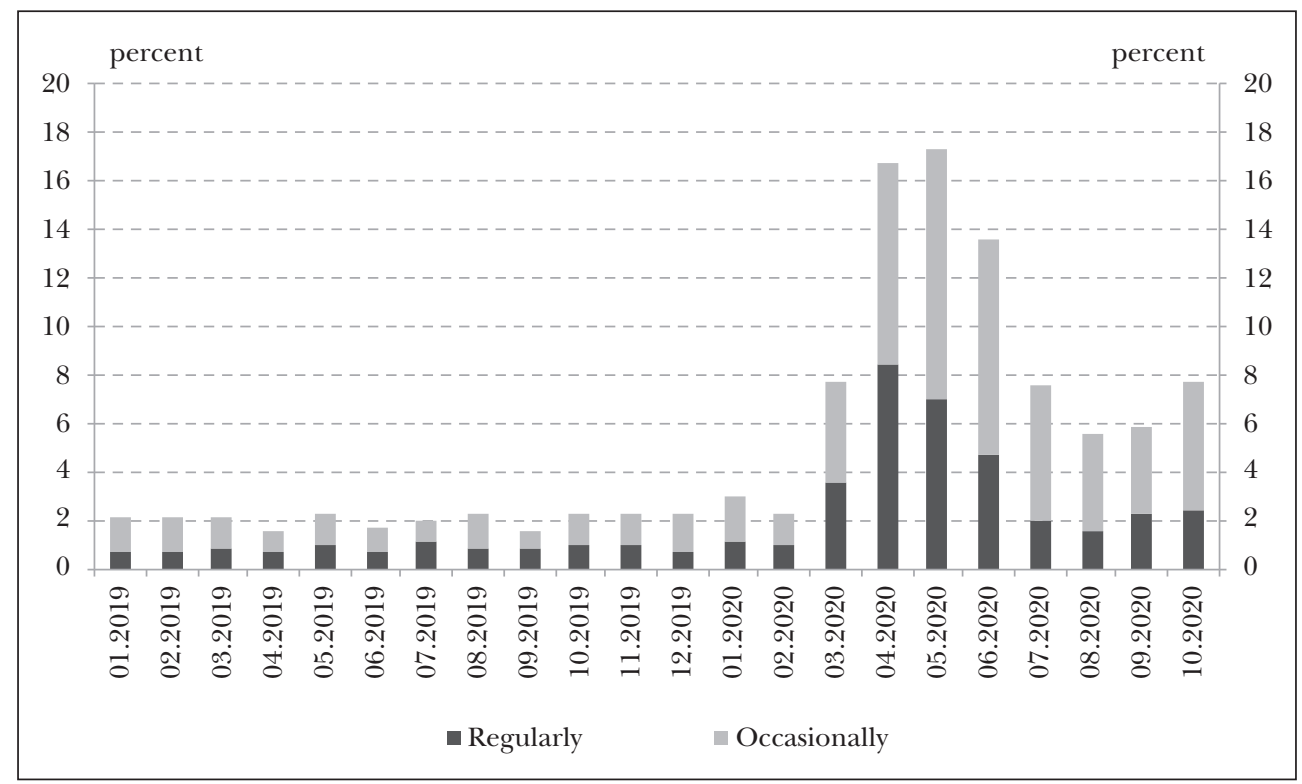

Source: KSH Heti Monitor (CSO Weekly Monitor)

The task is to take advantage of the opportunities offered by the newly built infrastructure and to implement the digital transition of the Hungarian economy. An experiment conducted by a Chinese company in 2010-2011 shows that teleworking increased employee productivity by a third, halving the number of employees leaving, while the company saved thousands of dollars per employee per year during the period under review (Bloom, 2014). Today, everything is in place to take permanent advantage of the benefits of teleworking. Let us not miss this opportunity. The expansion of atypical forms of employment, such as teleworking or part-time employment, holds a significant reserve, which is essential for achieving the economic growth needed for sustainable convergence. Countries with a high share of atypical jobs have the highest employment rates. So far, Hungary has lagged behind the Western European countries in this regard (Magyar Nemzeti Bank, 2019c), but now it has received a new impetus in this area as well. This is indeed necessary, since, for demographic reasons, a stronger improvement in the employment rate is needed to increase the number of employees. 


\section{György Matolcsy: Quo vadis Hungaria? - Facing a New World}

What will this mean for employees and employers in everyday life? Both the shape and atmosphere of workplaces will change. Workplaces may focus more and more on the non-contact design of premises, regular disinfection and the provision of social distance. There will be a lower personal presence in the offices. In the future, it will no longer be the default for all employees to be in the office every working day. All this will mean a more flexible relationship between workers and workplaces, which, at the same time, will be able to take better account of individual needs. The demand for this among today's young people has already emerged, which has posed significant challenges for employers in recent years. Another change will be that, from now on, work will be more easily accessible from home or even any other place, which will amplify the spread of digital nomad lifestyle. An increasing number of employees will be freelancers living on occasional assignments ("gig economy"), which will make it easier for companies to carry out project-type tasks, but will make it more difficult to fill jobs that require performing regular tasks. Although Budapest ranks high (8th) in the global ranking of cities for digital nomads, there is still room for development in many areas, where those more successful than us can serve as good examples.

In new ways - the society around us is transforming

The curfew restrictions due to the pandemic is that they have broken the routine of everyday life and created an opportunity for us to stop a little while with our family and think about our lives. Let us not be afraid to change our previous lifestyle or even our workplace if we feel that we can do better than that. Let us dare to embark on the search for new ways, as on the untrodden roads we can find great treasures. During this period, the task of economic policy is to open up these new roads and to facilitate the exploitation of opportunities. Let us defend the results we have achieved through many years of work, let us continue to strive for full employment. Let us think about how we can create at least as many, but even more productive jobs that generate more value.

In a crisis situation, it really becomes clear whom you can truly count on. Fortunately, Hungarian families did well in this field, too, as, for example, the transition of the education system to a digital curriculum or the public health care system to a pandemic control mode has been successfully implemented, and elderly family members have not been left without help either. This last one is extremely important, as international research shows that the impact of social relations on life prospects is greater than, for example, that of smoking or even obesity (Holt-Lundstad et al., 2010). However, the social relations of the elderly have decreased remarkably over the past few months due to their vulnerability. So the task is clear: we must pay attention to our elderly family members and the elderly living in our neighbourhood, talking to them and helping them adapt to the new situation. Engaging them in the digital world is now truly possible: let us provide them with digital tools and teach them how to use them. The Hungarian Government has recognised it right that in the current situation, not only those losing their jobs but also the elderly need help, so the gradual re-introducing of the 13th-month pension and the following message is to be welcomed: "No Hungarian is alone." 
Civic Review · Vol. 16, Special Issue, 2020

Digitalisation, digitalisation, digitalisation - the health care and education system are transforming

The Hungarian economic policy is facing one of its biggest challenges in history: in order to achieve a successful convergence, we need to implement a turnaround in competitiveness that will help us break out of the middle income trap. The pandemic crisis has now provided an excellent opportunity for this. Economic-historical experience shows that rapidly developing economies run out of steam before they could reach the level of developed economies. In the last one hundred years, only barely a dozen countries (e.g. South Korea, Singapore and Finland) have been able to break out of this trap (Magyar Nemzeti Bank, 2019c). In order for Hungary to join these nations, we need to further develop our economic model and switch to a predominantly knowledge- and innovation-driven economic model as soon as possible.

The current pandemic situation has shown that digitalisation is also a key issue in ensuring a healthy and highly trained workforce. Both education and health care systems have switched overnight to digital operations worldwide. The only question is whether Hungary will succeed in exploiting the potential of this and, based on current experience, setting these systems up for a more successful and efficient operation.

It is possible to speed up health care reforms. We need to rethink the structure of health care system, whether we really need such long hospitalisations, or we can move towards the more efficient, lower-risk same-day care. We need to set up an infrastructural background for telemedicine to enable doctor-patient appointments to be conducted online. Furthermore, the relationship between public and private care systems should also be reconsidered. The MNB sees the resolution of this issue possible through the establishment of Supplementary Welfare Funds, which we have presented in detail in our Competitiveness Programme in 2019 (Magyar Nemzeti Bank, 2019c).

A key issue for the long-term success of digital education is that the challenges of the modern age can only be met through continuous self-improvement. In the digital curriculum, the way of accountability is changing, so the improvement of classical methods (questioning, school test) is necessary. We should note, however, that this creates an opportunity to transform the approach of our education system and to provide young people with knowledge that can be applied in everyday life. The results of international educational tests (TIMSS, PIRLS, PISA) show that Hungarian students duly acquire the specified curriculum but they are unable to use it appropriately in real life situations (Magyar Nemzeti Bank, 2019c). Of course, acquiring the knowledge that connects Hungarians and strengthens our identity, is still necessary, but in addition, more attention should be paid to the ability of students to recognise correlations and find the information they need. These are the skills that will make them successful in the future labour market. Today, the learning process does not stop at the school gate, neither in time nor in space. Digitalisation makes continuous self-improvement and lifelong learning much easier, since nowadays, we can take courses even from home, from our own couch at the world's best universities. 
György Matolcsy: Quo vadis Hungaria? - Facing a New World

This also means that global competition is intensifying in adult education, in which the Hungarian tertiary education system can only be successful if the transformations that have just begun take place.

Accelerating digitalisation and investing in it can become even more important in this situation. Economic policy can best help to accelerate the necessary investment with targeted subsidies and preferential loans, and loan guarantees. However, the increase in government involvement cannot stop at these two systems. The efficiency of the governance needs to be further increased through the digitalisation of public services, and companies need to be helped to respond successfully to the challenges posed by the economic structure transforming due to the pandemic. An increasing share of trade and services will move to the cyberspace in the future, which requires different knowledge and skills. The pandemic has now pushed everyone into the deep water, but the goal is for Hungarian enterprises to be as successful in the field of technological change too as Hungarian swimmers at the Olympics.

\section{WHAT ARE THE OPPORTUNITIES IN THE DEVELOPMENT OF MONETARY SYSTEM?}

It was already shown in the previous crises, but it has now become really clear that states need to renegotiate the conditions for money creation with participants of the financial system (Matolcsy, 2020c). There could be two likely outcomes of this process: one is the so-called Japanese way that entails the monetisation of debts, and the other is a new way that involves digital money and targeted central bank money creation. At the same time, a third way is also conceivable, which can be realised as a combination of the two, resulting in a kind of hybrid solution.

\section{Continuous monetisation of debts - The Japanese way}

The Japanese way means to continuously monetise debts, i.e. to take government and private debts into the central bank's balance sheet and to greatly increase the amount of money in the economy. In Japan, the stock-market and real-estate bubble that burst in the early 1990s caused the economy to shrink for several quarters and created a deflationary environment. In response, there were a number of attempts to boost the economy, including fiscal stimulus, recapitalisation of banks, reduction of the policy rate to 0 per cent, but the measures proved to be ineffective. This was exacerbated by the 2001 dotcom crisis, which led the central bank to start buying government bonds and treasury bills, monetising the government debt and thus increasing its balance sheet total and the amount of money in the economy. Following the 2008-2009 global economic crisis, this technique took an even more spectacular form, and became dominant after 2013. The Japanese way, therefore, means that central banks will retain the framework they have already established, while more extensive use of instruments will become typical. By following this way, central banks will continue their current practices and use their existing instruments aggressively and to a large extent. 
Civic Review · Vol. 16, Special Issue, 2020

However, Japanese practice may have significant limitations in the future, so it is more worthwhile to use existing assets in a targeted way. Although the monetisation of debts has proved to be successful in addressing money market imbalances and liquidity problems in the banking system, the extent of the impact on the real economy has been disputed. Thus, continued aggressive and high use of instruments does not necessarily pay off when considering the costs of the programmes.

The new way - Digital money and targeted central bank money creation

In the 21st century, like all areas of life, the financial system has undergone significant transformations. With the spread of digitalisation, financial innovations have also accelerated, which have only intensified in recent years with the emergence of newer and newer methods.

In addition to the development of existing technological solutions, with the spread of the Covid-19 pandemic, de-cashing has become even more important than before, which could create the need for the economy to have access to central bank money electronically. All this foreshadows that states will renegotiate the basics and conditions for money creation, thus central banks can have more direct contact with real economy. Cash is currently the only risk-free money-holding option available to economic agents. In the event of the exclusion of cash, households and companies would be left without having any option to hold risk-free central bank money. Without innovative central bank solutions, money creation and monetary transmission could, in extreme cases, get out of the control of central banks.

As part of the financial evolution, the era of digital money and targeted central bank money creation can come. In this revolution, digital central bank money can take over the role of cash. Digital central bank money is a legal means of payment issued by the central bank. It is electronic, widely accessible (to consumers and non-financial corporations), and available continuously, every day of the year and every hour of the day (Meaning et al., 2017). In addition, the central bank can decide whether to allow anonymity to be granted, so this aspect depends largely on the attitude of the central bank. Contrary to the current financial system, in the concept of digital central bank money, the central bank would provide account management services to non-financial corporations and households as well. These new types of money can fundamentally rewrite the way financial systems are operating and the process of money creation. Therefore, many central banks are researching the topic of digital central bank money. The Covid-19 pandemic has brought the examination of the concept even more to the forefront, and countries that previously did not allow any discussion about it have also become open to the topic. At the same time, there are still many open questions about digital central bank money, and its widespread use still needs to be realised.

With the help of central bank innovations, including digital central bank money, central banks will have a more direct contact with real economic agents. This also means that central banks can more easily influence the saving and investment decisions of economic agents, thereby directly controlling the amount of money circulating in the economy. 
György Matolcsy: Quo vadis Hungaria? - Facing a New World

All this is of particular importance in the event of a crisis, since in such cases financial assistance can be provided directly even to the households and corporations, without the involvement of the commercial banks. New digital solutions will improve the effectiveness of monetary transmission. Due to the changed regulation and money creation conditions, states will have an even stronger presence in the private financial system.

\section{A hybrid financial system can also be developed}

In connection with the new equilibrium of money creation, a third type of system can also be developed, which could be realised as a combination of the Japanese way being transformed in the current framework and a completely new financial system characterised by digital central bank money. This type of regime can be equated to a one-and-a-half-tier banking system, where commercial banks can still play an important role, but as a kind of complement, central banks can also directly finance the expenditures of economic agents. The implementation of this system can have several desirable effects, mainly due to its flexibility. First, it captures and takes advantage of the wide and extensive set of instruments offered by the Japanese way. Second, the creation of digital central bank money can improve the effectiveness of monetary transmission. In this way, monetary policy can have an even more targeted and effective impact in the economic segments where the need for intervention arises.

\section{Crisis management strategy of the Magyar Nemzeti Bank}

A new world and new norms await us

After a decade of great success also in terms of economic history, Hungary faced an unexpected global health emergency in early 2020. The Covid-19 pandemic and the ensuing economic crisis have posed and continue to pose extraordinary challenges today for both societies and all economic agents. The crisis has been and is being addressed effectively in those countries where state decision-making is fast, public confidence is strong, the economy is successful and public services are functioning properly (Matolcsy, 2020e). For the first time in the last one hundred years, Hungary was able to tackle a crisis in such a way that its economy had strong foundations and its economic policy had sufficient room for manoeuvre. With successful health care protection and coordinated economic policy responses, the convergence status of the Hungarian economy can be maintained despite the pandemic.

In addition to addressing the short-term consequences, a longer-term perspective must be kept in mind as well. Countries that are rapidly adapting to the new norms of the new - postCovid-19 pandemic - world too, will be able to win the next decade. The role of the state providing protection - state institutions will be the key actors -, fast decisionmaking and effective cooperation between economic policies and economic agents will become even more valuable (Matolcsy, 2020b). The pandemic is also accelerating 
Civic Review · Vol. 16, Special Issue, 2020

a number of existing megatrends of the 21st century, and new ones can be born as well. In this international competition, we need to find Hungary's place and identify what factors can give us a competitive advantage. We need to further strengthen the outstanding features of today's Hungarian economy, and we will continue to need the bold, innovative economic policy we have seen over the last decade. The first test of this is to successfully address the current crisis.

Competitiveness factors need to be strengthened further

In the future, we need to further develop the Hungarian growth model: to preserve our strengths and our achievements so far and to make inventive use of our reserves in order to be the winners of the new megatrends. By strengthening the factors of competitiveness, Hungary can become a very attractive economy in terms of capital, technology, trade and finance.

We need to make sure that we maintain the successful growth formula of recent years through targeted economic protection measures. In other words, we need to maintain dynamic investment, expanding consumption - supported by wage increases, family benefits and an efficient tax system - and the 2-3 per cent growth surplus - based on advanced technology, high capital intensity and double-digit credit expansion - compared to the European Union average (Matolcsy, 2020a). Balance and growth are needed at the same time for sustainable convergence.

In the current situation and in the near future, we must strive to accelerate all investment, primarily in the public sector but, with the encouragement of the state, everywhere. Protecting companies, preserving jobs and rebuilding jobs lost during the coronavirus crisis are key to protect the economy. We must take action, speeding up everything, where the pace we are accustomed to in favourable conditions is no longer enough. These rapid steps can be supported by targeted job protection and investment promotion programmes covered by budgetary resources.

Early access to funds on favourable terms for companies and households should be supported by new central bank programmes and by the acceleration of cash flow (Matolcsy, 2020a). With the launch of the Instant Payment System in March, it has become possible to transfer money to anyone within seconds at any time of the day. As a result, transactions can be completed quickly, either at the point of payment or without a personal presence. This programme further increases the efficiency of domestic cash flow, the competitiveness of the payment market and the Hungarian economy, and is an important milestone in reducing more expensive use of cash.

Monetary policy must play an active role in crisis management

Following the turnaround in monetary policy in 2013, the MNB - in addition to its primary goal of achieving and maintaining price stability - made a significant contribution to financial stability and the strengthening of the real economy through targeted, innovative new instruments by boosting lending and reducing external financial vulnerability. 


\section{György Matolcsy: Quo vadis Hungaria? - Facing a New World}

In a considerably more uncertain, rapidly changing macroeconomic environment caused by the Covid-19 pandemic, the inflation target remains a priority for the central bank, but to achieve this it is necessary to protect the Hungarian economy, the financial system and society. The economic downturn jeopardises the achievement of the inflation target, while the instability of the financial system threatens the effectiveness of monetary policy, so in order to maintain price stability, monetary policy must provide the necessary financial liquidity for all economic agents through its measures, thereby supporting financial stability and rapid economic recovery in line with its mandate. In the current situation, the effective crisis management of the Magyar Nemzeti Bank requires the recognition of the specificities of the main economic policy challenges caused by the Covid-19 pandemic and, on this basis, the use of targeted tools adapted to the needs of the actors.

Due to the spread of Covid-19 pandemic, monetary policy has faced money market challenges, such as deteriorating liquidity conditions in financial markets, risk aversion to emerging markets - including Hungary -, the lack of cheap and stable financing options available to the corporate sector or the weakening of monetary policy transmission. Because of the crisis, liquidity in dominant domestic financial markets typically decreased and long-term government securities yields rose markedly.

In this environment, domestic monetary policy must simultaneously maintain the balance of the economic and financial systems and make a significant contribution to the restart of the economy. To this end, monetary policy must achieve stability in short-term yields, moderation in long-term yields - which can ensure favourable financial conditions on a permanent basis - and, most importantly, the availability of sufficient liquidity for all sectors.

The MNB has taken a number of measures to alleviate money market tensions caused by the Covid-19 pandemic (Figure 7). The measures in the crisis management of domestic monetary policy focus on both the short and long sections of the yield curve. Short-term assets serve basically to maintain balance and stability. In addition, during the summer 2020, the Monetary Council reduced the base rate in two steps by 30 base points overall, of which level of 0.60 percent supports in a sustainable manner the price stability, the preservation of financial stability and the recovery of economic growth. The role of long-term yields in monetary policy decision-making has become more pronounced in recent years as the interest period of household loans has increasingly shifted to the long side, and longer-term assets have become dominant in savings, too. Accordingly, in order to increase the efficiency of monetary policy and to lay the foundations for economic recovery, the central bank has also decided to introduce and use longerterm assets.

In order to kick-start economic growth, it is essential to prevent credit market disturbances, so the MNB has launched the latest phase of the Funding for Growth Scheme (FGS), which aims to provide micro-, small and medium-sized enterprises with widely usable, favourable funding. Loans taken up under the FGS Go! can be used by companies for investment purposes, current asset financing, replacement of existing loans and even for wage payments. There has been significant interest by companies in the 
Civic Review · Vol. 16, Special Issue, 2020

Figure 7: Monetary policy measures introduced to deal with the crisis caused by the Covid-19 pandemic
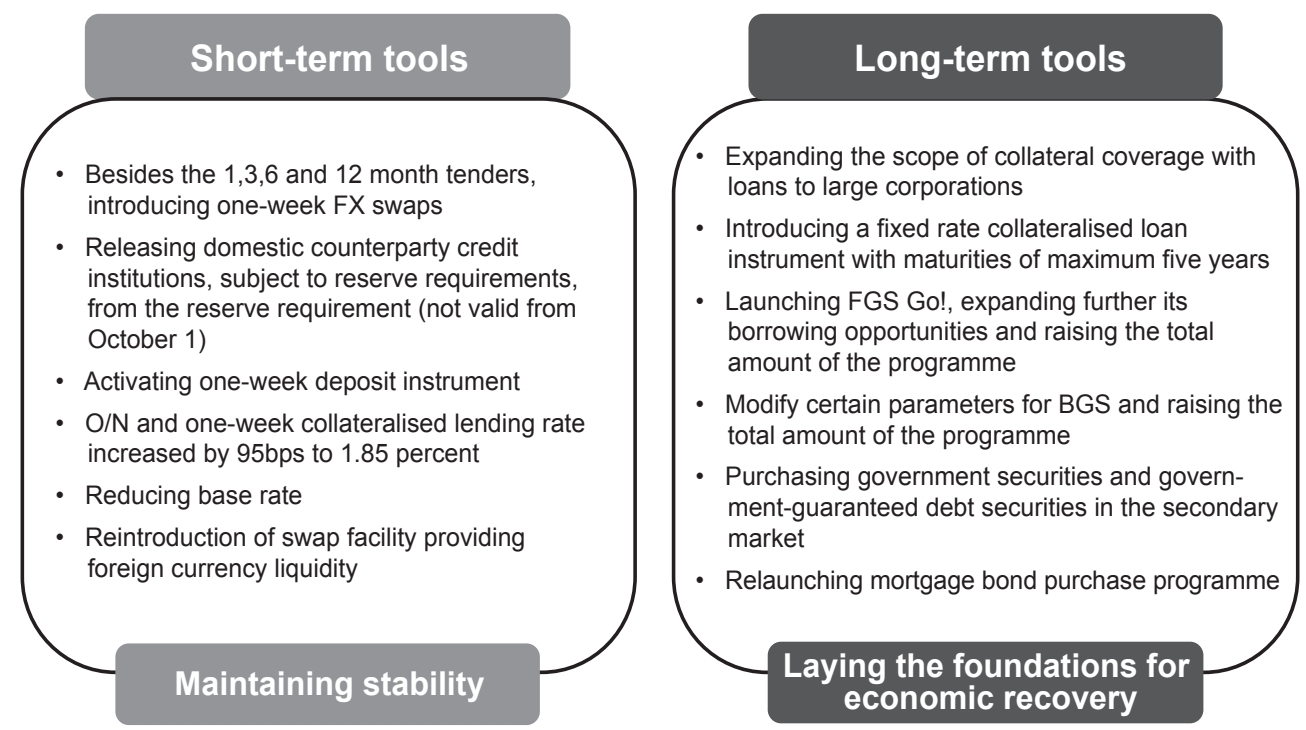

Source: $M N B$

programme since it was launched in April.. Due to the high utilization of the programme, at its November meeting the Monetary Council raised the total amount of the FGS Go! by HUF 1,000 billion. The central bank helps to increase liquidity in the corporate bond market by modifying certain parameters of its corporate bond purchase programme, the Bond Funding for Growth Scheme (BFGS) and by raising the total amount of the programme.

In order to improve the effectiveness of monetary policy, the MNB has also launched an asset purchase programme, whereby it makes government securities purchases on the secondary market under a flexible framework. The programme successfully contributed to maintaining a stable liquidity position in the government securities market, strengthened the effectiveness of monetary policy transmission, and supported the extension of the maturity structure of government debt. The MNB continues its asset purchase programme with a lasting market presence and will use the purchases to the extent and to the time necessary. In addition, in early October the central bank changed the strategic parameters of the government securities purchase programme and extended the range of assets available for purchase to government-guaranteed debt securities issued. The central bank has provided the banking system with additional long-term liquidity by having relaunched its mortgage debenture purchase programme. The programme has previously successfully developed the mortgage bond market, increasing mortgage bond issuance, reducing the premium on mortgage bonds relative to government securities and reducing the premium on fixed mortgages (Magyar Nemzeti Bank, 2018). 
György Matolcsy: Quo vadis Hungaria? - Facing a New World

Overall, Magyar Nemzeti Bank provided around HUF 5,000 billion additional financial resource to the economy in 2020 which accounts for more than 10 percent of GDP.

\section{There is still room for manoeuvre}

Contrary to global trends, the MNB's balance sheet has shrunk markedly in recent years in a way that, at the same time, the central bank has implemented significant, targeted monetary easing. The strategy of keeping the domestic central bank balance sheet at a low level is really appreciated in these difficult times, because it allowed the MNB to respond to the negative economic effects of the coronavirus pandemic with a significant expansion in its balance sheet, and thereby supporting the recovery of economic growth. The MNB's balance sheet can still be considered of average size in regional comparison, despite a significant expansion this year.

Economic policy decision-makers need to keep in mind that at present - as opposed to the situation caused by the outbreak of the 2008 crisis - we are not dealing with a crisis of the system or a system of crises but with difficulties that need to be resolved in a targeted way (Matolcsy, 2020e). This solution is served by the MNB's instruments consisting of expanded and targeted measures as well as the size and structure of the central bank's balance sheet, which provide substantial room for manoeuvre in terms of responses to future challenges later on. Domestic monetary policy has adequate firepower and, if necessary, can use all the weapons at its disposal.

\section{SUMMARY}

Since 2013 the Hungarian central bank's monetary policy turnaround has been a basis for economic growth and, at the same time, it has promoted a sustainable balance, so Hungary faced the Covid-19 pandemic and its economic effects with a strong immune system. However, this new type of crisis is accelerating the emergence of new norms and new megatrends. The world is rapidly changing around us, thus economies that become the frontrunners in existing and emerging new megatrends can win the next decade. Deglobalisation, digitalisation, green transformation and changing consumer behaviour are global trends that no one can remove themselves from. By recognising and benefiting from these megatrends and strengthening factors of competitiveness like efficient governance and digital education, Hungary can rise and be among these economies. Central banks must play an active and innovative role in making effective use of these trends and the Magyar Nemzeti Bank is ready to take part in this process.

\section{REFERENCES}

Bank for International Settlements (2018): Cryptocurrencies: Looking Beyond the Hype. In: BIS Annual Economic Report 2018. www.bis.org/publ/arpdf/ar2018e5.pdf.

Bloom, N. (2014): To Raise Productivity, Let More Employees Work from Home. Harvard Business Review, January-February. 